\title{
Chest imaging in patients with suspected COVID-19
}

\author{
Scott J. Adams MD, Carole Dennie MD
}

Cite as: CMAJ 2020 June 22;192:E676. doi: 10.1503/cmaj.200626; early-released May 22, 2020

1 c cosing Chest imaging is not routinely recommended to diagnose coronavirus disease 2019 (COVID-19) in patients with mild features ${ }^{1}$ The diagnosis of COVID-19 is based on clinical symptoms and a positive reverse-transcription polymerase chain reaction (RT-PCR) assay. ${ }^{1}$ Chest radiography has been reported to have $25 \%-69 \%$ sensitivity, with limited data regarding specificity, ${ }^{2,3}$ compared with computed tomography (CT), which has a $44 \%-98 \%$ sensitivity and $25 \%-53 \%$ specificity. ${ }^{1,4}$

2 In patients with risk factors for disease progression, chest radiography, together with clinical symptoms, may inform whether to follow up in the community or to refer to secondary care Risk factors for disease progression include age older than 65 years and comorbidities such as cardiovascular disease, diabetes, chronic respiratory disease, hypertension and immunocompromise. ${ }^{5} \mathrm{~A}$ low threshold for additional imaging is suggested for patients with risk factors. ${ }^{6}$ Hospital admission is considered for patients with moderate (e.g., dyspnea but blood oxygen saturation $\geq 94 \%$ on room air) and severe disease (e.g., marked tachypnea, hypoxemia, and substantial lung involvement on chest radiograph). ${ }^{6}$

\section{A normal chest radiograph or CT scan does not rule out COVID- $19^{3}$}

Chest imaging is often normal in patients with mild and early disease. ${ }^{3,4}$ Findings peak 6-13 days after symptom onset..$^{3,4}$ Imaging features, though not specific, include consolidation and faint ground-glass opacities, particularly with a bilateral, peripheral, or posterior, lower zone distribution. ${ }^{3,4}$ (Appendix 1, available at www. cmaj.ca/lookup/suppl/doi:10.1503/cmaj.200626/-/DC1). Differential diagnoses include other viral infections, adverse drug reaction and organizing pneumonia. ${ }^{1}$

\section{Chest CT should be considered for some patients}

In patients with new or worsening symptoms, chest CT can be useful to rule out complications such as a lung abscess, empyema, pulmonary embolism, or superimposed bacterial pneumonia., ${ }^{1,5}$ Chest CT may also be useful in moderately to severely symptomatic patients with a negative RT-PCR to either suggest the diagnosis of COVID-19 (if typical imaging features are found) or exclude alternative diagnoses. ${ }^{1,5}$

Repeat imaging is not indicated unless there is a change in clinical status, such as increased respiratory distress, or complications are suspected ${ }^{5}$

Repeat imaging increases patients' radiation exposure and the risk of health care providers and other patients contracting the virus. Daily chest radiography in stable patients with COVID-19, including intubated patients, does not lead to improved outcomes. ${ }^{1}$

\section{References}

1. Dennie C, Hague C, Lim RS, et al. The Canadian Society of Thoracic Radiology (CSTR) and Canadian Association of Radiologists (CAR) Consensus Statement Regarding Chest Imaging in Suspected and Confirmed COVID-19. Ottawa: CSTR and CAR; 2020 Apr. 17. Available: https://car.ca/wp -content/uploads/2020/04/CSTR-CAR-Consensus-Statement -Regarding-Chest-Imaging-in-Suspected-or-Confirmed -Covid-19.pdf (accessed 2020 Apr. 22).

2. Choi H, Qi X, Yoon SH, et al. Extension of coronavirus disease 2019 (COVID-19) on chest CT and implications for chest radiograph interpretation. Radiol Cardiothorac Imaging 2020;2:e200107. doi: 10.1148/ryct.2020200107.

3. Wong HYF, Lam HYS, Fong AH-T, et al. Frequency and distribution of chest radiographic findings in COVID-19 positive patients. Radiology 2019 Mar 27:201160. [Epub ahead of print]. doi: 10.1148/radiol.2020201160.

4. Simpson S, Kay FU, Abbara S, et al. Radiological Society of North America expert consensus statement on reporting chest CT findings related to COVID-19. Endorsed by the Society of Thoracic Radiology, the American College of Radiology, and RSNA. J Thorac Imaging 2020; Apr. 28. [Epub ahead of print]. doi: 10.1097/RTI.0000000000000524.

5. Rubin GD, Haramati LB, Kanne JP, et al. The role of chest imaging in patient management during the COVID-19 pandemic: a multinational consensus statement from the Fleischner Society. Radiology 2020; Apr. 7:201365. [Epub ahead of print]. doi: 10.1148/radiol.2020201365.

6. Gandhi RT, Lynch JB, del Rio C. Mild or moderate COVID-19. N Engl J Med 2020; Apr. 24. [Epub ahead of print]. doi: 10.1056/NEJMcp2009249.

\section{Competing interests: None declared.}

This article has been peer reviewed.

Affiliations: Department of Medical Imaging (Adams), University of Saskatchewan, Saskatoon, Sask.; Departments of Radiology and Medicine (Dennie), University of Ottawa, Ottawa, Ont.

Online resources available for chest imaging and management of COVID-19 are available in Appendix 2, www.cmaj.ca/lookup/suppl/ doi:10.1503/cmaj.200626/-/DC1

Correspondence to: Scott Adams, scott. adams@usask.ca 